\title{
ERGOSTEROL: KLÍČOVÝ STEROID HUB
}

\author{
Vlastimil Dohnal 1,2,3, Alena Ježková ${ }^{1}$, Jiř́i Skládanka 4
}

10: $247-482,2008$

${ }^{1}$ Mendelova zemědělská a lesnická univerzita v Brně, Agronomická fakulta, Ústav technologie potravin 2 Univerzita obrany, Fakulta vojenského zdravotnictví, katedra toxikologie

${ }^{3}$ Univerzita Jana Evangelisty Purkyně v Ústí nad Labem, Přírodovědecká fakulta, katedra chemie

4 Mendelova zemědělská a lesnická univerzita v Brně, Agronomická fakulta, Ústav výživy zviřat a pícninářství

\section{ÚVOD}

V prrírodě se vyskytují látky, jejichž produkce je vázána na jeden či více druhů organismů a které plní specifickou, pro daný organismus životně důležitou, funkci. Jedním z členů této skupiny látek je i sloučenina se steroidní strukturou ergosterol (obr. 1).

Ergosterol se vyskytuje pouze v houbách, plísních a některých mikroorganismech, jako jsou kvasinky či trypanosomy, které vyvolávají spavou nemoc. V organismu je lokalizován v buněčných stěnách, kde zajišt’uje správnou funkci lipidické membrány. $\mathrm{Na}$ jeho př́tomnost je vázána permeabilita buněčné membrány a aktivita membránových enzymů. Vyskytuje se také v cytosolu, kde plní důležité funkce při procesech látkové výměny. Fyziologická funkce ergosterolu u kvasinek tkví v účasti na regulaci proteinkinázy, která je potřebná pro iniciaci růstu. Dále slouží např́iklad k podpoře syntézy fosfatidylinositolu.

Ergosterol je v čisté formě bílou krystalickou látkou. Je velmi dobře rozpustný $\mathrm{v}$ tucích, naopak je prakticky nerozpustný ve vodě. Strukturně je velmi blízký cholesterolu, nejznámějšímu sterolu savců. Liší se pouze v prrítomnosti methylové skupiny vázané na uhlík C-24 a dvou dvojných vazeb mezi uhlíky $7-8$ a 22-23. Jeho hydrolýzou v alkalickém prostředí nevzniká ve vodě rozpustný produkt, čímž se liší od lipidů, podléhajícím zmýdelnění.

Obr. 1 Strukturní vzorec ergosterolu

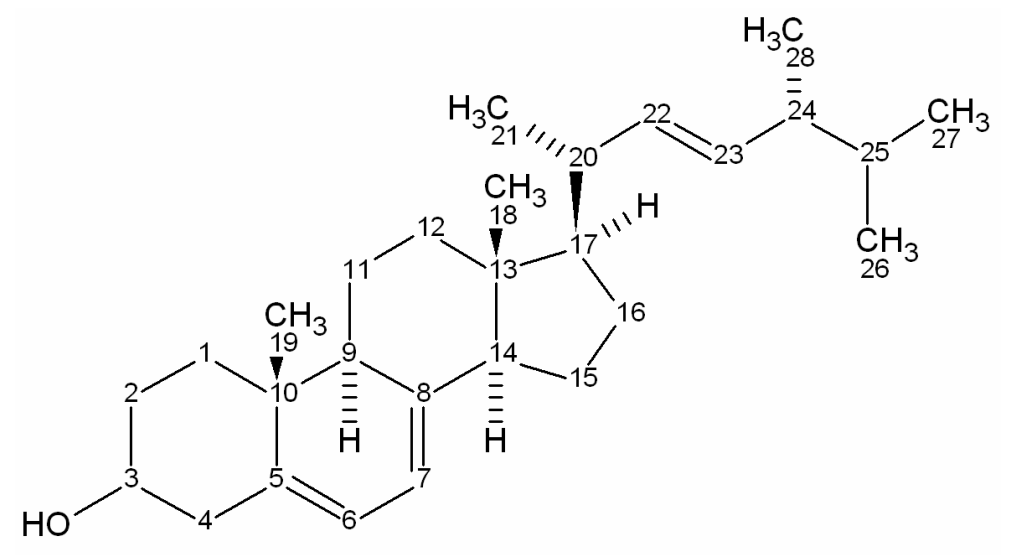




\section{Objev ergosterolu}

Přestože jsou kvasinky známy jako významný producent ergosterolu, byl tento sterol poprvé izolován ze sklerocií parazitické houby paličkovice nachové (námele, Claviceps purpurea), rostoucí na žitě. První izolaci provedl a pojmenování ergosterol pro tuto látku použil pař́žžsý lékárník Charles Tanret roku 1889, který vycházel z pojmenování nemoci (ergotismu), kterou námel u lidí vyvolává (Vandamme et al., 1989). Teprve o několik let později Gérard (1895) popsal výskyt ergosterolu v kvasinkách a v plísních.

Obsah ergosterolu v sušině plísní se pohybuje průměrně kolem $0,6 \%$ ( $\mathrm{v}$ některých př́padech až 2,2 \%, Penicillium westlinghi); u kvasinek se běžně vyskytuje $\mathrm{v}$ desetinách procenta $(0,1-$ $0,2 \%), v$ některých př́padech může však dosáhnout $\mathrm{i}$ jednotek procent (2-9 \% u Saccharomyces cerevisae) (Vandamme, 1989). V současné době byly vytvořeny geneticky modifikované kvasinky S. cerevisae, schopné rychle a ve velkém množství produkovat ergosterol (He, 2007).

\section{Plísním na stopě}

Hlavním důvodem, proč je vhodné a často i nutné sledovat výskyt plísní, je jejich nepř́iznivé působení na potraviny či krmiva. Plísně mohou za určitých podmínek produkovat toxické metabolity - mykotoxiny, které jsou prrícinou celé řady epidemických otrav (Morgavi, 2007; Richard, 2007). Mají také vliv na výživovou hodnotu, protože ke svému růstu spotřebovávají živiny, jako jsou tuky a sacharidy a také esenciální aminokyseliny (lysin, cystein) V neposlední řadě dochází $\mathrm{k}$ organoleptickým změnám potravin a krmiv - změna barvy, vůně, konzistence, chuti (Vieira, 2003). Také monitorování přítomnosti plísní v obytných prostorách, ulicích měst či ve skladištích potravinových surovin má velký význam.

Vzhledem $\mathrm{k}$ tomu, že produkce ergosterolu je vázána prakticky jen na houby a některé druhy kvasinek, se nabízí idea: kde je ergosterol, tam musí být jejich producenti, a to zejména plísně. Otcem myšlenky využití stanovení ergosterolu jako indikátoru přítomností plísní v cereáliích byl kolektiv vědců kolem Seitze. Ten také v roce 1977 popsal jednoduchou metodu extrakce a stanovení pomocí kapalinové chromatografie (Seitz, 1977).

Dalšími výzkumy bylo zjištěno, že obsah ergosterolu v plísních napadajících potravinové suroviny ve skladištích není významně ovlivněn podmínkami, ve kterých rostou. Tento poznatek otevřel cestu $\mathrm{k}$ možnosti využití obsahu ergosterolu jako, „indexu“ množství fugální biomasy. Později se však ukázalo, že situace nemusí být tak jednoduchá a při nižším obsahu vody v substrátu může být korelace mezi ergosterolem a počtem kolonií plísní mnohem menší. Za definovaných environmentálních podmínek je však možné velmi přesně stanovit množství plísní v daném materiálu.

Trendem do budoucnosti je snaha vytvoření modelu produkce ergosterolu plísněmi za různých environmentálních podmínek. Pokud se navíc podaří vyvinout model, který kromě produkce ergosterolu zahrne i produkci toxických sekundárních metabolitů plísní, bude možné předpovídat potenciální environmentální faktory, za nichž dochází $\mathrm{k}$ napadení plísněmi a $\mathrm{k}$ produkci mykotoxinů. Největší význam modelů tkví $\mathrm{v}$ minimalizaci rizika růstu plísní v potravinách (Tothill, 2003). U pšenice je napríklad obsah ergosterolu také funkcí hmotnosti zrna, kde menší zrna obsahují relativně více ergosterolu než zrna větší. I nečistoty a úlomky zrn se vyznačují vyšším obsahem ergosterolu (Regner, 1994). Množství ergosterolu bylo navrženo jako jeden z nových parametrů kvality rajčat a rajčatových výrobků (Kadakal, 2004).

Ergosterol je možné využít také jako indikátor napadené píce plísněmi. Jeho výskyt ukazuje na horší kvalitu píce. V lučních a pastevních porostech je výskyt plísní závislý na stanovištních a povětrnostních podmínkách. Stoupá zejména na konci vegetačního období, kdy jsou porosty náchylnější $\mathrm{k}$ onemocnění a saprofytům. Otázka plísní a s nimi spojených zdravotních problémů tak nabývá na významu při prodlužování pastevního období, resp. při celoročním pobytu zvírat na pastvinách. Výzkum, který proběhl na různých stanovištích v České republice, Německu, Polsku a Mad'arsku v letech 2000-2003, ukázal, že obsah ergosterolu v píci z travních porostů se na konci vegetačního období může pohybovat od 20 do $500 \mathrm{mg} \cdot \mathrm{kg}^{-1}$ sušiny. $\mathrm{V}$ průběhu podzimu dochází ke zvýšení obsahu ergosterolu. Náchylnost travního porostu khoubovým chorobám se tedy postupně zvyšuje. Fyziologicky starší porosty jsou k houbovým chorobám náchylnější. Porosty využívané pouze počátkem června vykazují kon- 
cem vegetačního období (listopad) vyšší produkci biomasy, ale také vyšší obsah ergosterolu v píci (70-220 mg.kg-1 sušiny). Naproti tomu porosty intenzivněji využívané mají koncem vegetačního období nižší produkci, ale kvalita píce je vyšší nejenom s ohledem na obsah živin, ale také s ohledem na výskyt plísní. Obsah ergosterolu se zde pohybuje od 10 do $160 \mathrm{mg} \cdot \mathrm{kg}^{-1}$ sušiny (Opitz von Boberfeld et al., 2006).

Rozdílná je také náchylnost jednotlivých druhů k houbovým chorobám (plísním). Náchylnější jsou jemnolisté druhy, jako je jílek vytrvalý (Lolium perenne L.) nebo lipnice luční (Poa pratensis L.). Naopak druhy s tuhými vzprrímenými listy jsou vůči houbovým chorobám odolnější. Ergosterol zde může opět sloužit jako indikátor fungálního napadení. V klimatických podmínkách Hesenska (Německo) byl v průběhu tř́ let u porostu jílku vytrvalého (Lolium perenne L.) zjištěn počátkem prosince obsah ergosterolu od 157 až po 314 mg.kg-1 sušiny. Naproti tomu u kostřavy rákosovité (Festuca arundinacea Schreb.) se ve stejném období obsah ergosterolu pohyboval pouze od 48 do $129 \mathrm{mg} \cdot \mathrm{kg}^{-1}$ sušiny. S obsahem ergosterolu zde souvisela také přítomnost mykotoxinu zearalenonu. Tento mykotoxin byl detekován pouze u porostu jílku vytrvalého (Lolium perenne L.) v množství max. 0,02 mg.kg-1 sušiny (Wolf, 2002). V našich pokusech na Českomoravské vrchovině byl v letech 2005 a 2006 u porostu ovsíku vyvýšeného (Arrhenatherum elatius L. P. Beauv) zjištěn koncem vegetačního období od října do prosince průměrný obsah ergosterolu $140 \mathrm{mg} \cdot \mathrm{kg}^{-1}$ sušiny a u srhy laločnaté (Dactylis glomerata L.) 137 mg.kg-1 sušiny. Festucoidní hybrid, krríženec kostřavy rákosovité (Festuca arundinacea Schreb.) a jílku mnohokvětého (Lolium multiflorum Lam.), vykázal nižší úroveň napadení houbovými chorobami, průměrný obsah ergosterolu byl 95 mg. $\mathrm{kg}^{-1}$ sušiny (Dohnal, 2007).

Prítomnost ergosterolu $\mathrm{v}$ prachu $\mathrm{z}$ domácností je známkou prítomnosti plísní a jeho množství koreluje s množstvím fugální biomasy. To přináší problém nejen s toxicitou spojenou s jejich metabolity. Negativní působení plísní tkví nejenom $v$ toxicitě některých jejich metabolitů, ale spóry mohou u některých jedinců působit jako alergeny. Ergosterol se do prachu dostává právě se spórami, kde se jeho koncentrace pohybuje kolem $1,0 \mu \mathrm{g} / \mathrm{mg}$ spór. Rozdíly mezi jednotlivými plísněmi jsou přibližně $25 \%$.
V celkovém množství prachu se pak jedná řádově o $0,7-45,0 \mu \mathrm{g} / \mathrm{g}$ prachu, respektive $0,01-$ 194,0 ng/m3 vzduchu. Množství ergosterolu nevypovídá o druhu plísní či zdravotním riziku, kterému jsou obyvatelé domu vystaveni (Sullivan, 2001).

Velmi zajímavým př́kladem využití stanovení ergosterolu je i sledování kvality odpadních vod v čistírně. Vyčištěná voda prochází nádobkou, ve které jsou pěstovány plísně, a průběžně je sledována produkce ergosterolu. Sníží-li se hladina ergosterolu, je zřejmé, že voda obsahuje toxické látky a není tedy dostatečně čistá (Padgett, 2000).

\section{Ergosterol jako cíl antimykotik}

Skutečnost, že ergosterol plní velmi důležité role v buňce, a díky tomu, že se nevyskytuje v živočišných buňkách, jsou látky, které vážou ergosterol (např́klad polyeny jako natamycin, Amphotericin B, nystatin apod.) nebo blokující jeho syntézu (azoly, alylaminy, morfoliny), používány jako antimykotika.

Polyeny, skupina přibližně 200 látek, jsou produkovány Streptomyces spp. a mají schopnost tvořit komplexy s ergosterolem. Snížení koncentrace volného ergosterolu vede ke snížení fluidity membrán, které se stávají více krystalickými a vytvářejí se $\mathrm{v}$ nich polární póry. $\mathrm{V}$ důsledku této změny je narušena integrita membrány buněk, které se stávají více permeabilní, a dochází $\mathrm{k}$ vytečení jejich obsahu, zejména iontů draslíku a sodíku i polárních látek. Tak masívní úbytek jednonásobně nabitých kationtů vede nevyhnutně ke smrti buňky.

Problémem aplikace polyenů je jejich interakce s cholesterolem a jinými steroly živočišných buněčných membrán, podobných ergosterolu. Způsobují tak kromě žádaného fungicidního účinku i poškození léčeného organismu, zejména ledvin, s následnou elektrolytovou disbalancí. Toxicita Amphotericinu B se může snížit jeho podáním např́klad ve formě lipidického komplexu, což umožní podávání vyšších terapeutických dávek.

Zatímco polyeny poškozují funkci membrány př́mou interakcí s ergosterolem, jiné skupiny antimykotik jsou založeny na inhibici jeho biosyntézy. Do této skupiny léků patři napríklad azoly (imidazoly, triazoly), alylaminy a morfoliny. Na tomto principu je založena nejen celá rada antifungálních látek, jako jsou léčiva či fungicidy. 
Narozdíl od polyenů působí azoly (Flukonazol, Itrakonazol), imidazoly (napríklad Clotrimazol, Mikonazol apod.), respektive morfoliny spíše jako fungistatika. Jejich nespornou výhodou je, že jsou prakticky netoxické. Azoly blokují enzym P450-Erg11P, který provádí demethylaci na C-14. Výsledkem je hromadění C14 methylovaného ergosterolu v buňkách a snížení množství ergosterolu. Methylovaný sterol je objemnější, nezapadá tak dobře do membránové struktury jako ergosterol. To má negativní vliv na enzymy vázané na membránu. Dochází k ovlivnění produkce chitinu, př́ijmu nutrietů a tím k zastavení růstu buňky, zastavení replikace a eventuálně k její smrti.

Další možností inhibice syntézy ergosterolu je inhibice dalšího enzymu, podílejícího se na jeho biosyntéze, skvalenepoxydázy, např́iklad alylaminy (Terbinafine, naftifin). Mechanismus účinku je obdobný jako u azolů - v buňce dojde $\mathrm{k}$ hromadění meziproduktu, $\mathrm{v}$ tomto případě skvalenu, a k deficitu ergosterolu. Výsledkem je opět narušení integrity buněčných stěn.

Morfoliny inhibují C-14 reduktázu a $\Delta 8 \rightarrow \Delta 7$ izomerázu. Výsledný efekt na buňku je obdobný jako u ostatních inhibitorů syntézy ergosterolu.

Místa působení jednotlivých druhů antimykotik jsou shrnuty v přehledném obrázku 2.

Blokace syntézy ergosterolu je též používána u antibiotických látek, které působí proti dalším organismům využívajících tento sterol. Jedná se především o kandidy, kryptokoky, ale i protozoa, které jsou původci leishmaniózy a malárie (Trypanosoma gambiense a T. rhodesiense, Plasmodium falciparum). Kromě toho, je i celá řada fungicidů založena na principu blokády tvorby ergosterolu v různých fázích jeho biosyntézy.

Obr. 2 Místa působení jednotlivých typů antimykotik

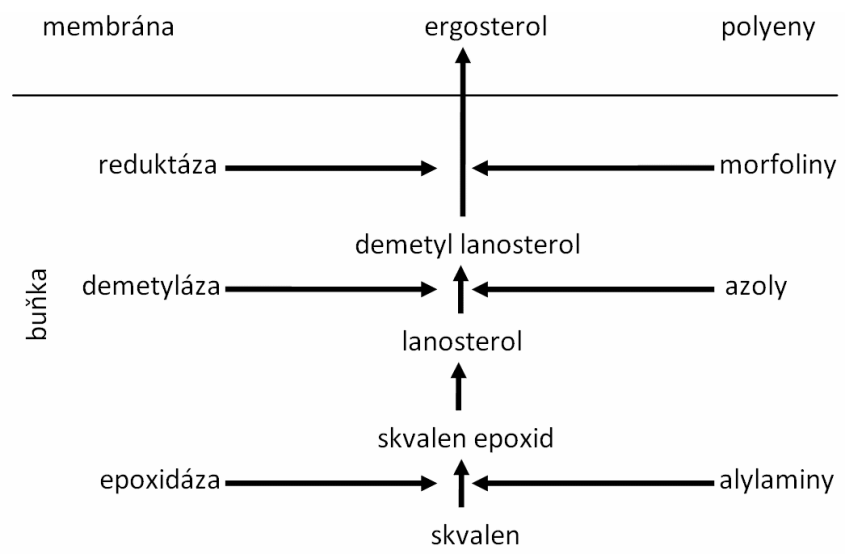

\section{Provitamin $\mathbf{D}_{2}$}

Vitamin D je potřebný zejména pro správný metabolismus minerálních látek a tvorbu kostí u savců a ptáků. Ovlivňuje hladinu vápníku, fosforečnanů a parathyroidního hormonu v krevním séru.

V roce 1924 Steenbock a Black prokázali, že ozáření potravy vede ke vzniku vitaminu D. O tři roky později, byla vyslovena hypotéza, že ergosterol je prekurzorem vitaminu D. V následujícím roce Windaus izoloval trí formy vitaminu $\mathrm{D}, \mathrm{z}$ toho dva rostlinné steroly, které pojmenoval vitamin $\mathrm{D}_{1}$ a $\mathrm{D}_{2}$ a jeden z ozářené kůže vitamin $\mathrm{D}_{3}$. Roku 1928 byla práce tohoto vědce, zabývající se výzkumem struktury sterolů a jejich vztahu $\mathrm{k}$ vitaminům, oceněna Nobelovou cenou. V roce 1932 byla definována chemická struktura vitamínu $\mathrm{D}_{2}$ a zaveden pojem ergokalciferol. Dnes jsou známé dva typy vitaminu $-\mathrm{D}_{2}$ a $\mathrm{D}_{3}$. Vitamin $\mathrm{D}_{1}$ jako chemická látka neexistuje, nebot' $\mathrm{v}$ původním objevu šlo o směs sloučenin (Bjorn, 2001).

Mechanismus vzniku vitaminu $\mathrm{D}_{2}$ je tedy následující: Ozářením ergosterolu dochází 
k otevření kruhu mezi atomy uhlíku 9 a 10, za vzniku viosterolu, který teplem izomeruje na ergokalciferol. Ten se později $\mathrm{v}$ játrech a pak v ledvinách mění na 10,25dihydroxyergokalciferol, aktivní formu vitaminu D (obr. 3).

Vitaminy $\mathrm{D}_{2}$ (ergokalciferol) a vitamin $\mathrm{D}_{3}$ (cholekalciferol) jsou u savců přibližně stejně účinné. U drůbeže je naopak účinnější vitamin $\mathrm{D}_{3}$ (Jelínek et al., 2003). Vitamin D má tři hlavní funkce. Ve stř̌evní sliznici indukuje biosyntézu bílkovin nezbytných pro resorpci iontů $\mathrm{Ca}^{2+}$, podporuje mineralizace kostí a pomáhá koordinovat také metabolismus fosfátů. Vitaminy $\mathrm{D}_{2}$ $\mathrm{a}_{3}$ jsou pro živočišný organismus metabolicky neaktivní. Aktivním se vitamin D stává postupnou přeměnou $\mathrm{v}$ játrech a ledvinách až na kalcitriol, který je nejúčinnějším metabolitem vitaminu D. Nedostatek vitaminu D způsobuje u mladých jedinců křivici (rachitis). Při nedostatku vitaminu D je snížená úroveň ukládání minerálních látek, což u rychle rostoucích kostí vede $\mathrm{k}$ deformaci a zvýšené lámavosti. U dospělých jedinců dochází k demineralizaci kostí, což způsobuje měknutí kostí (osteomalacii) a řídnutí kostí (osteoporózu). Při prudkém nástupu produkce mléka počátkem laktace může nastat u vysokoprodukčních dojnic tzv. poporodní paréza. Ve velkých dávkách je vitamin $\mathrm{D}$ toxický. Př́liš vysoký prísun vitaminu $\mathrm{D}$ vede k hypervitaminóze a následnému zvýšenému ukládání vápenatých solí v ledvinách, plicích, srdci a cévách.

Poznámka: Při stanovení ergosterolu se využívá absorpce záření právě při vlnových délkách odpovídající UV oblasti (282 nm) (Dohnal, 2006), takže paradoxně po detekci nemusí být $\mathrm{v}$ roztoku přítomen ergosterol, ale již produkt fotolýzy ergokalciferol.

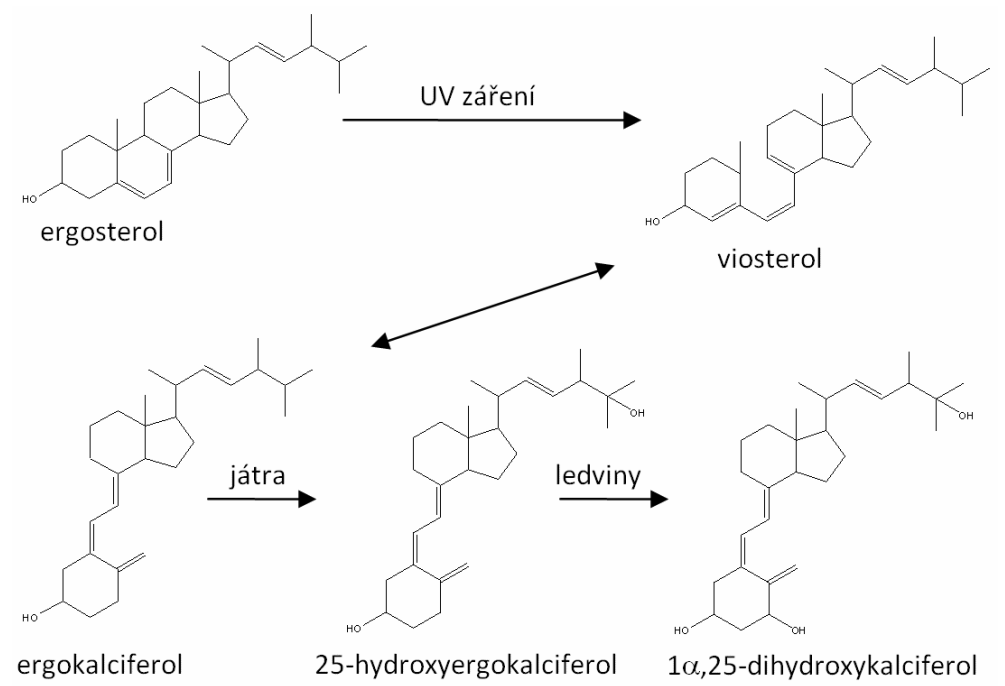

\section{ZÁVĚR}

Ergosterol jako hlavní steroid hub a některých mikroorganismů může sloužit nejen pro jejich detekci, ale částečně i kvantifikaci. Vyšší množství ergosterolu v potravinách může být znakem kontaminace plísněmi a tím i varováním před jejich další konzumací. Detekci ergosterolu je také možné využít v krmivářské praxi. Obdobně jako v lidské výživě ukazuje jeho zvýšený obsah na zoohygienickou závadnost krmiv. Kromě jiného má ergosterol pozitivní vliv na lidské zdraví, kdy po ozáření přechází na vitamin $\mathrm{D}_{2}$. Inhibice syntézy ergosterolu je základní funkcí celé řady antimykotik a antibiotik, které jsou účinné nejen proti mykózám, ale též proti pưvodcům nemocí jako jsou leishmanióza a malárie. V zemědělství jsou inhibitory syntézy ergosterolu použivány jako fungicidy. 


\section{LITERATURA}

BJORN, L. O., WANG, T.: Is provitamin D a UV-B receptor in plants? Plant Ecology, 2001. Vol. 154, no 1, s. 3 -8 .

DOHNAL, V., KADEROVÁ, I., JEŽKOVÁ, A., SKLÁDANKA, J.: Obsah ergosterolu u vybraných druhů trav na konci vegetačního období. Acta Univ. Agric. Silv. Mendel. Brunensis, 2007. Vol. 4, s. 9-14.

HE, X., GUO, X., LIU, N., ZHANG, B.: Ergosterol production from molasses by genetically modified Saccharomyces cerevisiae, Journal Applied Microbiology and Biotechnology, 2007. Vol. 75, no. 1, s. 55-60.

JELÍNEK, P., KOUDELA, K. et al.: Fyziologie hospodárských zviŕrat. 1. vyd., Brno: MZLU v Brně, 2003. 414 s.

KADAKAL, C., ARTIK, N.: A New Quality Parameter in Tomato and Tomato Products: Ergosterol. Critical Reviews in Food Science and Nutrition, 2004. Vol. 44, no 5, s. 349-351.

MORGAVI, D. P., RILEY, R. T.: An historical overview of field disease outbreaks known or suspected to be caused by consumption of feeds contaminated with Fusarium toxins. Anim. Feed Sci. Tech., 2007. Vol. 137, s. 201 --212 .

OPITZ VON BOBERFELD, W. et al.: Effect of different agronomical measures on yield of autumn saved herbage during winter grazing -- 2nd communication: Crude protein, energy and ergosterol concentration. Czech J. Anim. Sci., 2006. Vol. 51, no 6, s. 271-277.

PADGETT, D. E., MALLIN, M. A., CAHOON, L. B.

Evaluating the use of ergosterol as a bioindicator for as- sessing fungal response to water quality. Environ. Mon. Asses., 2000. Vol. 65, s. 547-558.

REGNER, S., SCHNURER, J., JONSSON, A.: Ergosterol content in relation to grain kernel weight. Cereal Chem., 1994. Vol. 71, no 1, s. 55-58.

RICHARD, J. L.: Some major mycotoxins and their mycotoxicoses-An overview. Int. J. Food Microbiol., 2007. Vol. 119 , no 12 , s. 3-10.

SEITZ, L. M., MOHR, H. E., BURROUGHS, R., SAUER, D. B.: Ergosterol as an indicator of fungal invasion in grains. Cereal Chem., 1977. Vol. 54, no. 6, s. $1207-1217$.

SULLIVAN, J. B., KRIEGER, G. R.: Clinical Environmental Health and Toxic Exposures, Lippincott: Williams \& Wilkins, 2001, s. 1029-1030.

TOTHILL, I.: Rapid and On-Line Instrumentation for Food Quality Assurance, Woodhead Publishing limited, Cambridge, Anglie, 2003, s. 150-157

VANDAMME, E. J.: Biotechnology of vitamins, pigments and growth factors, Springer, 1989. s. 81-94.

VIEIRA, S. L.: Nutritional implications of mould development in feedstuffs and alternatives to reduce the mycotoxin problem in poultry feeds. World's Poultry Sci. J., 2003., Vol. 59, s. 111-122.

WOLF, D.: Zum Effekt von Pflanzenbestand, Vornutzung und Nutzungstermin auf Qualität und Masse von Winterweidefutter. Dissertation. Giessen: Justus-Liebig Universität, $2002.127 \mathrm{~s}$. 